\title{
Archaeological Survey of the Proposed Lorence Creek Greenbelt, City of San Antonio, Bexar County, Texas
}

Jason D. Weston

Follow this and additional works at: https://scholarworks.sfasu.edu/ita

Part of the American Material Culture Commons, Archaeological Anthropology Commons, Environmental Studies Commons, Other American Studies Commons, Other Arts and Humanities Commons, Other History of Art, Architecture, and Archaeology Commons, and the United States History Commons

Tell us how this article helped you.

This Article is brought to you for free and open access by the Center for Regional Heritage Research at SFA ScholarWorks. It has been accepted for inclusion in Index of Texas Archaeology: Open Access Gray Literature from the Lone Star State by an authorized editor of SFA ScholarWorks. For more information, please contact cdsscholarworks@sfasu.edu. 


\section{Archaeological Survey of the Proposed Lorence Creek Greenbelt, City of San}

Antonio, Bexar County, Texas

\section{Creative Commons License}

\section{(c) (1) (8)}

This work is licensed under a Creative Commons Attribution-NonCommercial 4.0 International License 


\section{Archaeological Survey of the Proposed Lorence Creek Greenbelt, City of San Antonio, Bexar County, Texas}

by
Jason D. Weston

Prepared for:

Rehler Vaughn \& Koone, Inc. 745 East Mulberry St., Suite 601 San Antonio, Texas

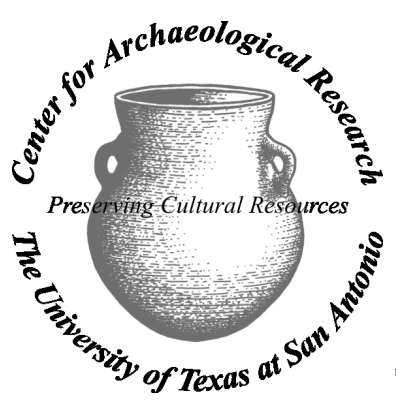

Center for Archaeological Research The University of Texas at San Antonio Archaeological Survey Report, No. 341 


\section{Archaeological Survey of the Proposed Lorence Creek Greenbelt, City of San Antonio, Bexar County, Texas}

by
Jason D. Weston

Principal Investigator

Steve A. Tomka

Texas Antiquities Permit No. 3085

Prepared for:

Rehler Vaughn \& Koone, Inc. 745 East Mulberry St., Suite 601

San Antonio, Texas

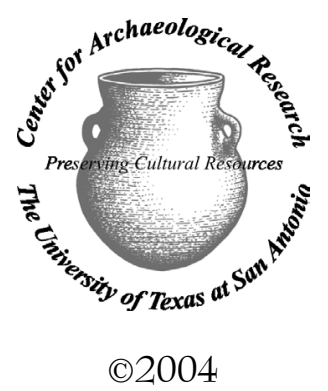

(ㅇ)2004
Prepared by:

Center for Archaeological Research The University of Texas at San Antonio Archaeological Survey Report, No. 341 
A list of publications offered by the Center for Archaeological Research is available. Call (210) 458-4378; write to the Center for Archaeological Research, The University of Texas at San Antonio, 6900 N. Loop 1604 W., San Antonio, Texas 78249-0658; e-mail to car@lonestar.utsa.edu; or visit CAR's web site at http://car.utsa.edu. 


\section{Abstract:}

Under contract with Rehler Vaughn \& Koone, Inc. of San Antonio, archaeologists from the Center for Archaeological Research (CAR) of The University of Texas at San Antonio conducted an archaeological survey of the proposed hikeand-bike trail along the Lorence Creek Greenbelt in San Antonio, Texas. The fieldwork was completed on April 1-2, 2003, under Texas Antiquities Permit No. 3085. Steve A. Tomka, Director of CAR, served as Principal Investigator. The goal of the survey was to determine the presence or absence of significant cultural materials in the area that may be impacted by the development of a proposed hike-and-bike trail within the greenbelt. The project area extends from Virgil T. Blossom Park 1.45 miles $(2.33 \mathrm{~km})$ along Lorence Creek downstream to within 750 feet of Jones Maltsberger Road. Archaeological investigations involved a $100 \%$ pedestrian survey and shovel testing within the project area.

The results of the survey indicate that the majority of the area along the footprint of the proposed hike-and-bike trail is disturbed by both natural and anthropogenic agencies. The survey efforts identified and documented one site41BX1581. The site contains a low density of cultural materials and no features. It is suggested that the site has minimal research potential. Therefore, even though the proposed trail runs along the edge of the site, it is suggested that the minimal construction activities associated with the trail be allowed to proceed as planned. All field documentation and all artifacts collected are permanently curated at CAR. 


\section{Table of Contents:}

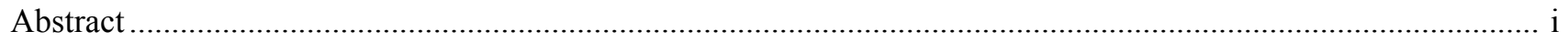

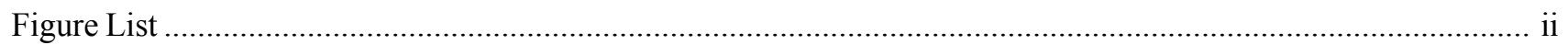

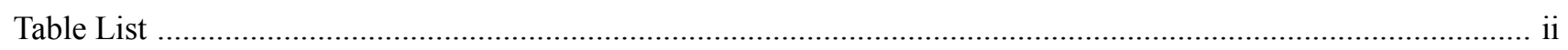

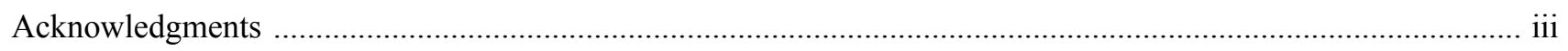

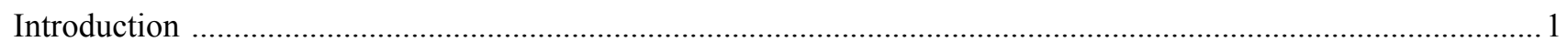

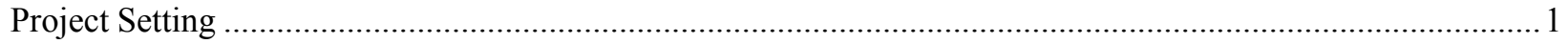

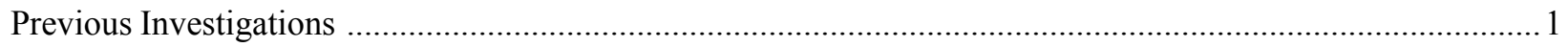

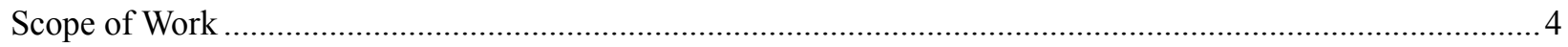

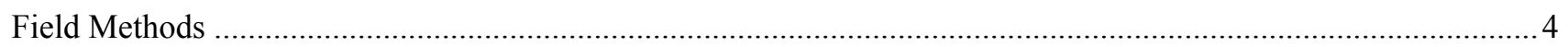

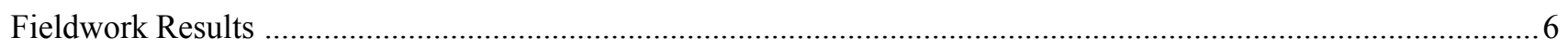

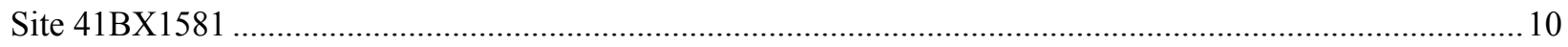

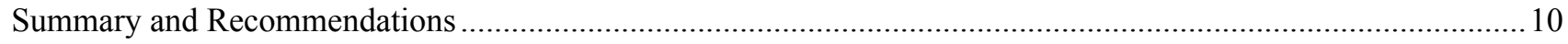

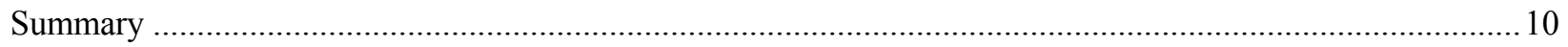

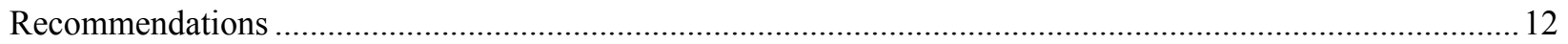

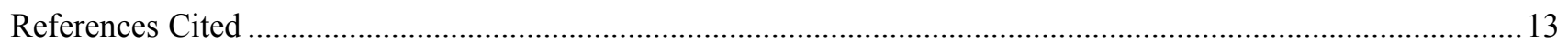




\section{Figures:}

Figure 1. Location of the project area on the Longhorn 7.5' Series USGS quadrangle map.................................2

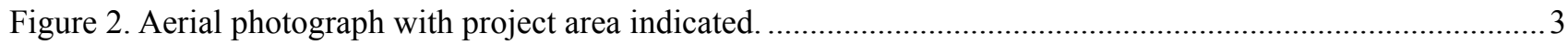

Figure 3. Exposed gravel deposits on the bank of Lorence Creek. …...............................................................

Figure 4. Example of landscaped banks near Lorence Creek. ........................................................................

Figure 5. Map of Section 1 of the project area, showing locations of Shovel Tests $1-7$. ......................................

Figure 6. Photograph of greenbelt in Section 1 of the project area. ....................................................................... 8

Figure 7. Map of Section 2 of the project area, showing locations of Shovel Tests $8-21$.................................. 9

Figure 8. Map of 41BX1581 showing locations of shovel tests, approximate site boundary,

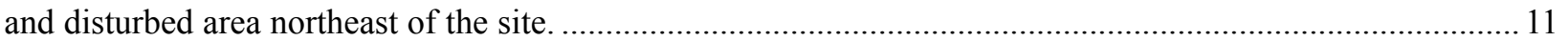

Figure 9. Biface fragment recovered from Shovel Test 16D, Level 2 (10-20 cmbs) ............................................ 12

\section{Tables:}

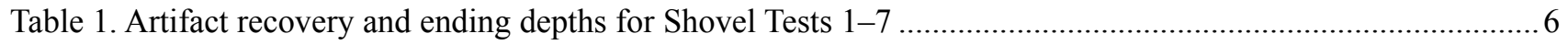

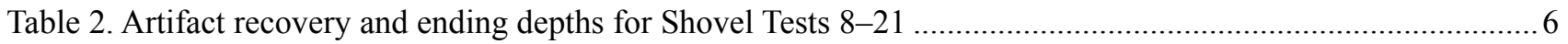




\section{Acknowledgments:}

The author would like to thank Dr. Steve A. Tomka, Director of CAR, for the initial scouting of the project area and his assistance in the planning of the project. Thanks also are due to Kimberly Wolf of Rehler Vaughn \& Koone, Inc. for her cooperation and assistance in facilitating the project. Jason D. Weston was the Project Archaeologist, assisted in the field by Stacy Wagner. The drafting by Bruce Moses and Rick Young, and technical editing by Johanna Hunziker and Barbara Meissner, is greatly appreciated. 


\section{Introduction}

On April 1-2, 2003 archaeologists from the Center for Archaeological Research (CAR) at The University of Texas at San Antonio, under contract with Rehler Vaughn \& Koone, Inc. of San Antonio, conducted a 100\% pedestrian survey and shovel testing of the Lorence Creek Greenbelt right-ofway (ROW). The purpose of this survey was to determine the presence or absence of cultural deposits that may be affected by the proposed construction of a hike-and-bike trail along the project area. The work was conducted under Texas Antiquities Permit No. 3085, with Dr. Steve A. Tomka, Director of CAR, serving as Principal Investigator.

\section{Project Setting}

The project area runs along Lorence Creek, a tributary of Salado Creek, which drains a portion of north-central San Antonio located between Highway 281 and Loop 1604 (Figure 1). The proposed greenbelt extends from Virgil $\mathrm{T}$. Blossom Park to the vicinity of Jones Maltsberger Road and McAllister Park. The planned trail begins near a short segment of an unnamed tributary of Lorence Creek that initiates immediately northwest of Virgil T. Blossom Park (Figure 2). The project area is approximately 1.45 miles $(2.33 \mathrm{~km})$ long and ranges between $160 \mathrm{ft} .(48.8 \mathrm{~m})$ and $700 \mathrm{ft}$. $(213.3 \mathrm{~m})$ wide, running between residential neighborhoods that are slowly encroaching on the already narrow streambed (Figure 2). Although the Area of Potential Effect is $160-700$ feet wide, the ROW of the actual hikeand-bike trail is projected to be only $7-10$ feet wide along its length. The entire width of the project ROW was surveyed to identify archaeological resources that may not be directly in the path of the trail but may nonetheless be impacted by public use of the facility.

Much of the project area consists of relatively flat channel deposits and areas of exposed bedrock (Figure 3). The stream banks have been landscaped and sculpted along extensive portions of the project area, removing much of the alluvial deposits that had the potential to contain buried cultural materials (Figure 4). The creek drains undivided Cretaceous Edwards limestone formations at its northern end. In this area, most of the sediments have been scoured by intermittent high-velocity flooding episodes.

\section{Climate}

The climate of Bexar County is subtropical and subhumid, with mild winters and warm to hot summers (Taylor et al. 1991). January highs average $61^{\circ} \mathrm{F}$ and lows average $38^{\circ} \mathrm{F}$.
July highs average $95^{\circ} \mathrm{F}$ with lows of $75^{\circ} \mathrm{F}$ (Bomar 1995:214-222). The growing season at San Antonio averages about 267 days a year (Bomar 1995:214-222).

Bomar (1995:228-230) notes that normal annual precipitation at San Antonio is 30.98 inches. Precipitation during the year tends to be bimodal, with an initial peak occurring in May (mean $=4.22$ in.) and June (mean $=3.81$ in.), and a secondary peak in September (mean $=3.41 \mathrm{in}$.) and October (mean $=3.17 \mathrm{in}$.). The driest period of the year is between December and March, when precipitation averages roughly 1.64 inches per month. These average precipitation totals mask considerable variability. For example, average annual precipitation has varied from a high of 52.28 inches in 1973 to a low of 10.11 inches in 1917 (Bomar 1995:228). This variability is common and displays very little periodicity or trend (Norwine 1995:143).

\section{Soils}

The soils in the immediate vicinity of the active channel are described as frequently flooded Trinity and Frio soils (Tf; Taylor et al. 1991). Outside of the active channel, the soils on the edges of the project area are identified as Crawford and Bexar clay and stony soils $(\mathrm{Ca}$ and $\mathrm{Cb})$. The soils near the southeastern end of the project area are identified as part of the Tarrant association (Taylor et al. 1991). Overall, the sediments are relatively thin and represent a mixture of clay and stony matrix. With such thin sediments, the limestone bedrock is frequently exposed in the creek. Within the limestone and chert gravels are occasional pieces of chert debitage and cores visible in the secondary context of the creek bed. These artifacts have been washed downstream from the higher terraces now covered by urban sprawl.

\section{Previous Investigations}

Earlier investigations in the general vicinity of the project area have documented the existence of archaeological sites within the relatively undeveloped McAllister Park immediately to the southeast of the project (Fox 1973, 1977; Tomka and Robinson 2000). Previous archaeological investigations conducted by CAR have located sites all along Salado Creek and its tributaries, such as nearby Mud Creek (Hester et al. 1974; Katz 1987; McGraw and Valdez 1978). Most of these sites are prehistoric and contain a variety of lithic artifacts (Hester et al. 1974; Katz 1987; McGraw and Valdez 1978). No previously recorded sites exist within or in the immediate vicinity of the project area. This survey represents the first archaeological investigation along this portion of Lorence Creek. 


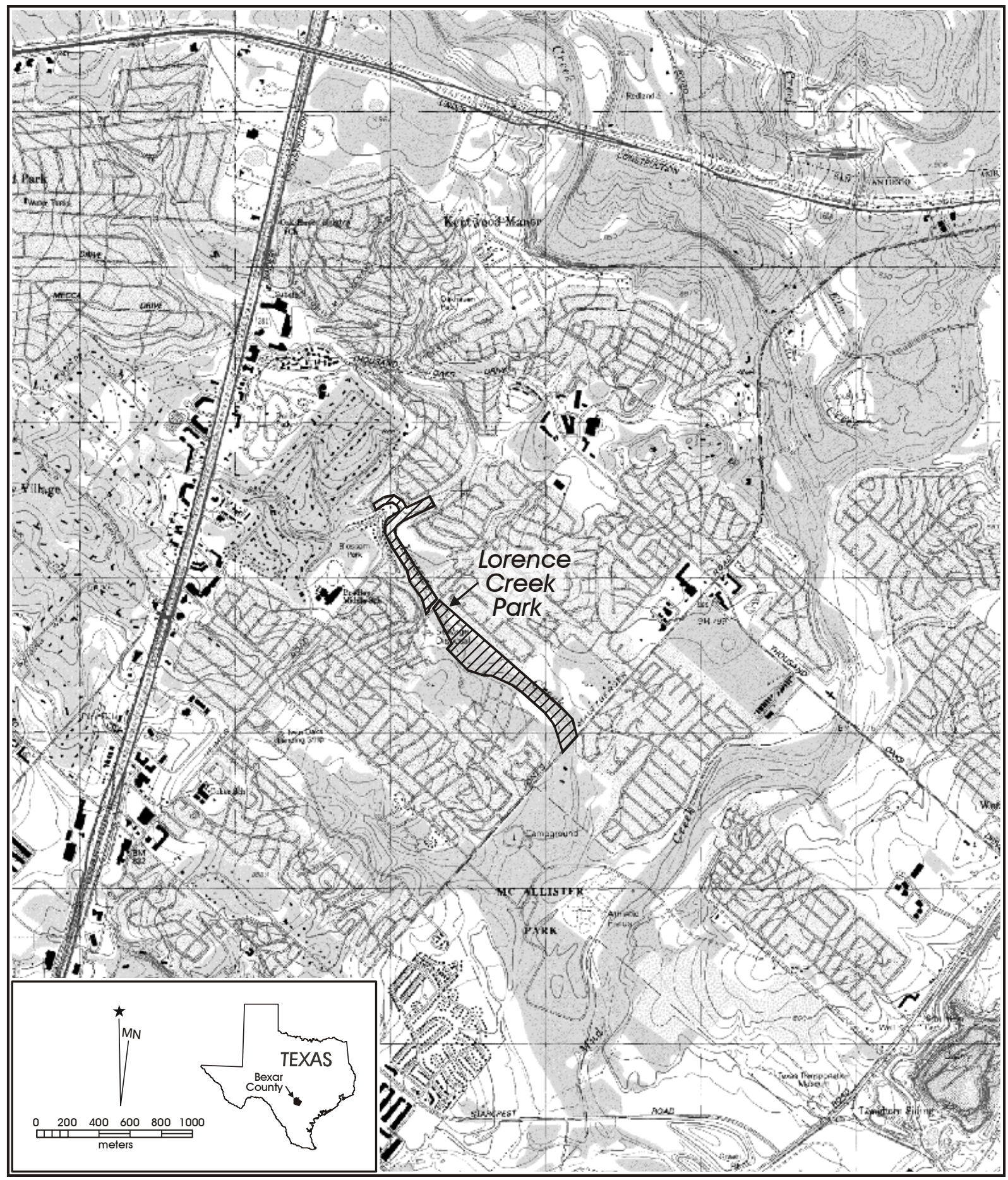

Figure 1. Location of the project area on the Longhorn 7.5' Series USGS quadrangle map. 


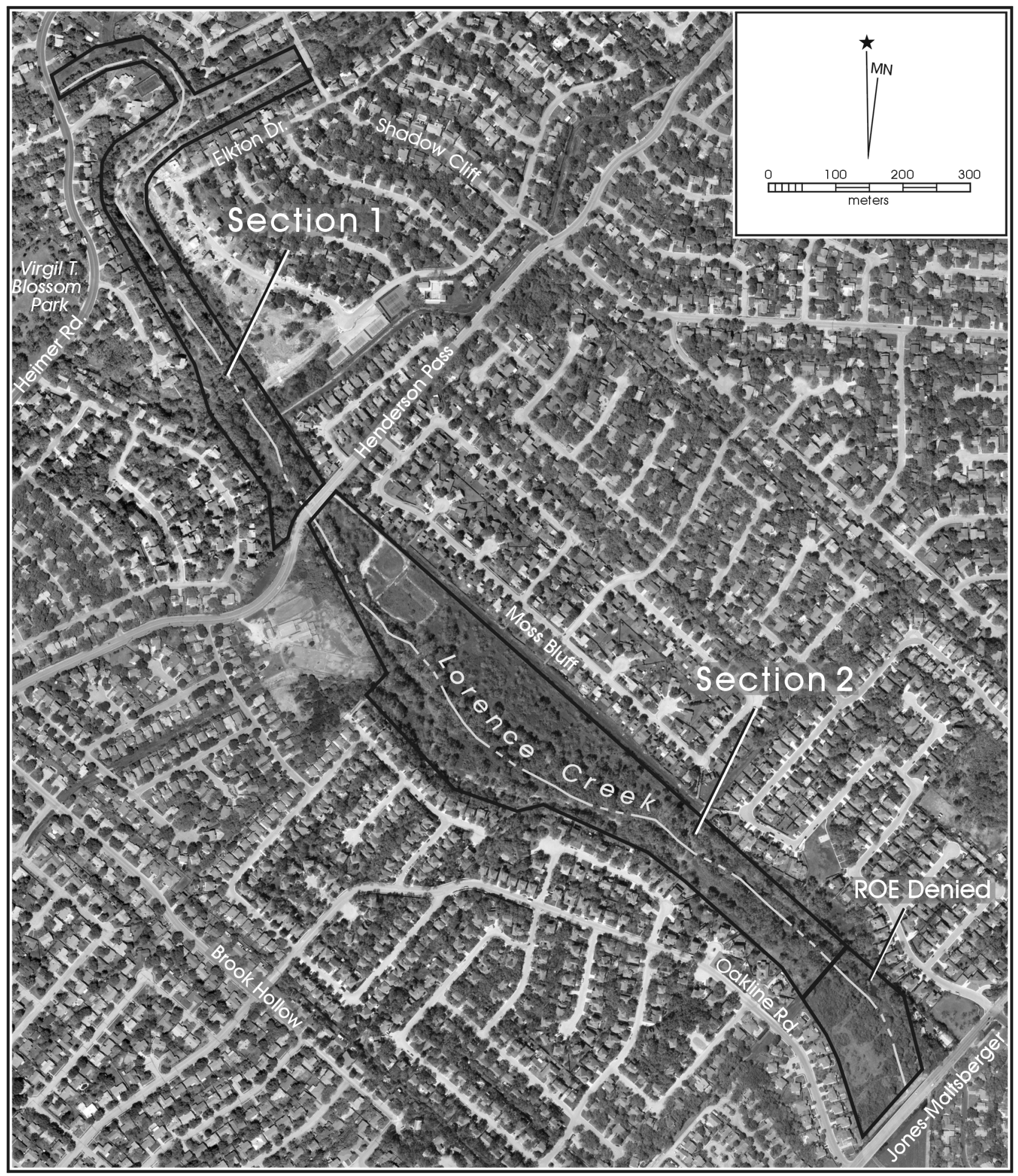

Figure 2. Aerial photograph with project area indicated. 


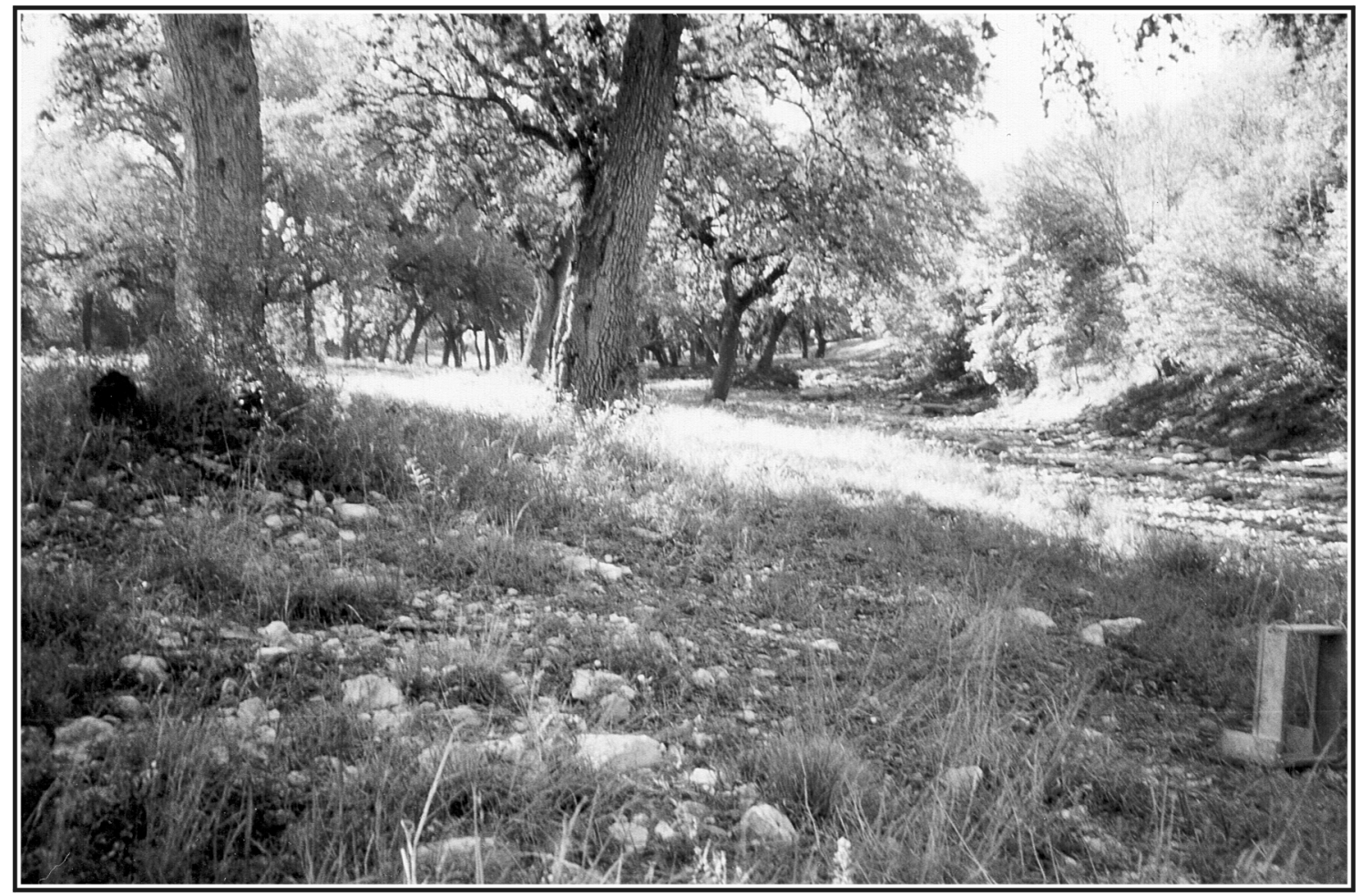

Figure 3. Exposed gravel deposits on the bank of Lorence Creek.

\section{Scope of Work}

The scope of work called for a $100 \%$ pedestrian survey of the project area, with shovel testing at a rate of 16 shovel tests per linear mile. Given the 1.45 mile ROW, a minimum of 24 shovel tests were planned for the project area. Based on a preliminary project area visit, it was considered unlikely that sediments too deep to reach by shovel test (i.e., deeper than $70 \mathrm{~cm}$ ) would have accumulated in the project area. However, the scope of work stated that if, during the survey and shovel testing, it was shown that aggrading depositional contexts too deep to explore by shovel testing were present in the project area, mechanically excavated backhoe trenches would be utilized to test such areas. Only technologically or temporally diagnostic prehistoric artifacts were to be collected during the pedestrian survey. In addition, all prehistoric artifacts recovered from the shovel tests were to be collected.

\section{Field Methods}

The fieldwork consisted of a $100 \%$ pedestrian linear survey of the project area using 30-m transect spacing where the project area outside of the active creek bed was sufficiently wide to necessitate more than a single transect. In addition, a minimum of 24 shovel tests (16 per linear mile) was planned for the 1.45 -mile $(2.33-\mathrm{km})$ project area. As expected, sediments along the project ROW proved to be shallow, less than $70 \mathrm{~cm}$ deep, so that the backhoe trenching proposed in the scope of work was not necessary.

Twenty-nine shovel tests were excavated during the survey of the project area. For fieldwork management purposes, the project area was divided into two sections: Section 1 extends from the northernmost part of the project area to Henderson Pass; Section 2 extends from Henderson Pass south to within $750 \mathrm{ft}$. (228.6 m) of Jones Maltsberger Road 


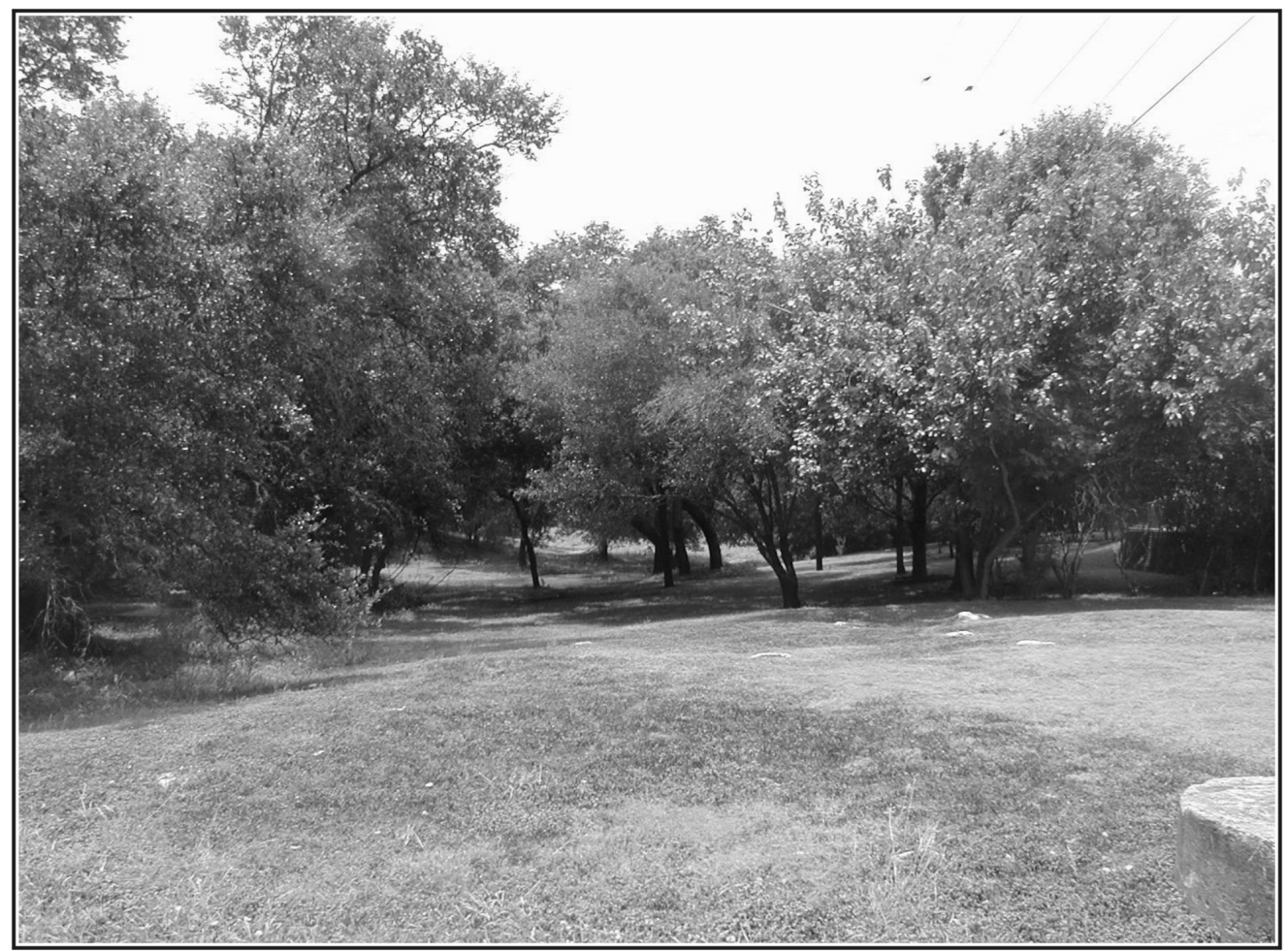

Figure 4. Example of landscaped banks near Lorence Creek. Note creek channel under trees.

(Figure 2). Seven shovel tests (were excavated in Section 1, while 22 shovel tests were excavated in Section 2. Shovel tests were $30-35 \mathrm{~cm}$ in diameter, and were dug until limestone gravels overlying the bedrock in the project area were encountered. Shovel tests were excavated in arbitrary $10-\mathrm{cm}$ levels, and all sediments from each level were screened through $1 / 4$-inch hardware cloth. All prehistoric artifacts recovered from the shovel tests were collected and bagged by provenience.

A standard shovel test form was completed for each excavated shovel test. Data collected from each shovel test included the final excavation depth, a tally of all materials recovered from each 10-cm level, and a brief soil description (texture, consistency, Munsell color, inclusions). The location of every shovel test was mapped using Trimble GeoExplorer II Global Positioning System (GPS) units. The proposed route of the hike-and-bike trail had been previously marked with flagging tape. This proposed route was also mapped using GPS units. As a backup to GPS provenience information, shovel test locations were also sketched onto a topographic map. Any additional observations considered pertinent were included as comments on the shovel test excavation forms and field notes.

All collected artifacts were returned to the CAR laboratory for processing, analysis, and curation. The processing, washing, sorting and cataloging of the artifacts and records was carried out according to CAR curatorial standards (http:/ /car.utsa.edu/curation/curationprocedures.htm). Each artifact was bagged in a 4-mil polyethylene re-closeable bag along with an acid-free curation tag that provides all specific provenience (i.e., location, depth), count, analytical class, and in some instances, artifact descriptions. All records were placed in archivally stable, acid-free folders. All original field forms stained by dirt were placed in sheet protectors. An electronic database of the catalog has been placed on a CD-ROM and is curated with the records. All records and artifacts will have permanent housing at CAR. 


\section{Fieldwork Results}

Much of the project area consists of the active channel of Lorence Creek. Many areas were scoured to bedrock, and where thin sediments were present, they consisted of Houston Black clays and silty clays (10YR 2/1). Localized pockets of deeper sediments were present. In these areas, the black clays changed to dark brown (7.5YR 3/2) clays by $35 \mathrm{cmbs}$ ( $\mathrm{cm}$ below surface) and became dark reddish brown (5YR3/3) clays between $35 \mathrm{cmbs}$ and $45 \mathrm{cmbs}$. The gravel layer that sits just above the bedrock ranged from $5 \mathrm{cmbs}$ to $68 \mathrm{cmbs}$ across the project area. The average depth of contact with this gravel layer was $32 \mathrm{cmbs}$. Many shovel tests were terminated as shallow as $10 \mathrm{cmbs}$ due to the thin sediments (Tables 1 and 2).

Section 1 of the proposed greenbelt hike-and-bike trail runs from Heimer and Shadow Cliff roads to Henderson Pass (see Figure 2 and Figure 5). This area is characterized by a wide, gravel-bottomed creek bed and low banks (Figure 6). Shovel Test 1 (ST 1) through ST 7 were located in Section 1 (Figure 5). An attempt was made to space the shovel tests every $100 \mathrm{~m}$, however, due to the wide stream channel and extremely shallow sediments, shovel testing was not possible over much of Section 1.

Each shovel test ended at contact with the limestone and chert gravel layer associated with the bedrock. In Section 1, this gravel layer was no deeper than $30 \mathrm{cmbs}$, and was often as shallow as $10 \mathrm{cmbs}$ (Table 1). ST 1 recovered one piece of unmodified lithic debitage from Level 2 (10-20 cmbs). Associated with the piece of debitage was a piece of reddyed pumice (not collected). Pumice is common to late twentieth to early twenty-first century suburban landscaping and propane gas grills. Its presence suggests that the sediments at this location are of recent origin and the

Table 1. Artifact recovery and ending depths for Shovel Tests 1-7

\begin{tabular}{|c|c|c|}
\hline ST\# & Level (cmbs) & Material Recovered \\
\hline \hline \multirow{2}{*}{01} & $1(0-10)$ & - \\
\cline { 2 - 3 } & $2(10-20)$ & 1 chert debitage \\
\hline 02 & $1(0-10)$ & - \\
\hline 03 & $1(0-10)$ & - \\
\hline 04 & $1(0-10)$ & - \\
\hline 05 & $1-3(0-30)$ & - \\
\hline 06 & $1(0-10)$ & - \\
\hline 07 & $1(0-10)$ & - \\
\hline
\end{tabular}

prehistoric flake is in a secondary context. A small piece of clear glass was encountered in Level $1(0-10 \mathrm{cmbs})$ of ST 2 , it was not collected.

Table 2. Artifact recovery and ending depths for Shovel Tests 8-21

\begin{tabular}{|c|c|c|}
\hline ST\# & Level (cmbs) & Material Recovered \\
\hline 08 & $1(0-11)$ & 2 chert debitage \\
\hline \multirow{3}{*}{09} & $1(0-10)$ & 2 chert debitage \\
\hline & $2(10-20)$ & 1 chert debitage \\
\hline & $3-5(20-42)$ & - \\
\hline 09A & $1(1-5)$ & - \\
\hline 09B & $1-7(0-68)$ & - \\
\hline 09C & $1-4(0-40)$ & - \\
\hline 10 & $1-4(0-40)$ & - \\
\hline 11 & $1-4(0-38)$ & - \\
\hline 12 & $1(0-10)$ & - \\
\hline \multirow{3}{*}{13} & $1(0-10)$ & - \\
\hline & $2(10-20)$ & 1 chert debitage \\
\hline & $3-4(20-40)$ & - \\
\hline 14 & $1-4(0-39)$ & - \\
\hline 15 & $1-4(0-43)$ & - \\
\hline \multirow{3}{*}{16} & $1(0-10)$ & 1 chert debitage \\
\hline & $2(10-20)$ & 1 chert debitage \\
\hline & $3-4(20-45)$ & - \\
\hline \multirow{5}{*}{$16 \mathrm{~A}$} & $1(0-10)$ & - \\
\hline & $2(10-20)$ & 1 chert debitage \\
\hline & $3(20-30)$ & - \\
\hline & $4(30-40)$ & 1 chert debitage \\
\hline & $5(40-42)$ & - \\
\hline \multirow{3}{*}{$16 \mathrm{~B}$} & $1(0-10)$ & 1 chert debitage \\
\hline & $2(10-20)$ & 1 chert debitage \\
\hline & $3-5(20-43)$ & - \\
\hline $16 \mathrm{C}$ & $1-5(0-48)$ & - \\
\hline \multirow{5}{*}{$16 \mathrm{D}$} & $1(0-10)$ & - \\
\hline & $2(10-20)$ & 1 thin chert biface \\
\hline & $3(20-30)$ & 2 chert debitage \\
\hline & $4(30-40)$ & 1 chert debitage \\
\hline & $5(40-50)$ & - \\
\hline $16 \mathrm{E}$ & $1-5(0-46)$ & - \\
\hline \multirow{2}{*}{17} & $1(0-10)$ & 2 chert debitage \\
\hline & $2(10-20)$ & - \\
\hline 18 & $1-4(30-40)$ & - \\
\hline 19 & $2(0-19)$ & - \\
\hline \multirow{2}{*}{20} & $1(0-10)$ & 1 chert debitage \\
\hline & $2-6(10-60)$ & - \\
\hline 21 & $1-3(0-30)$ & - \\
\hline
\end{tabular}




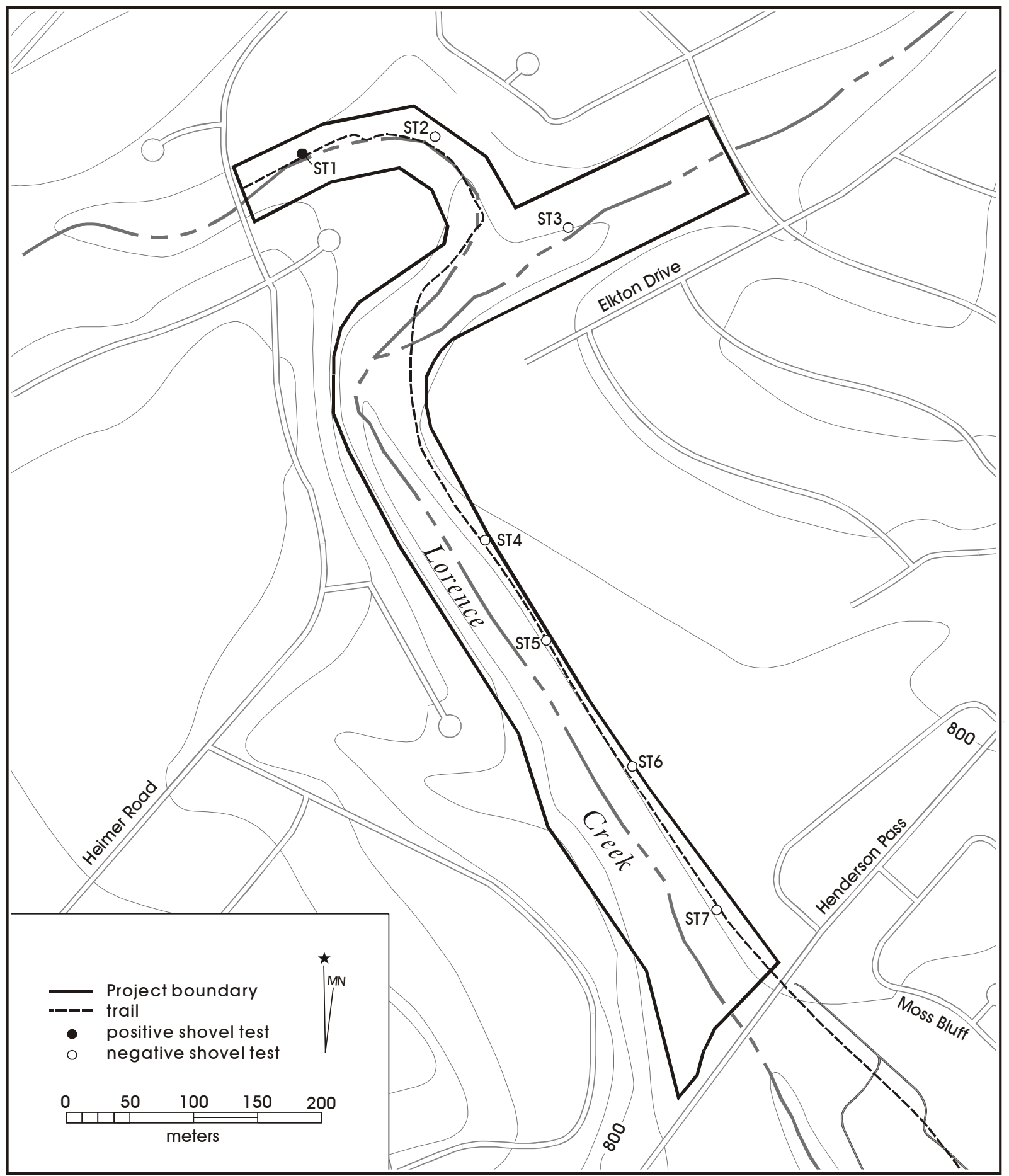

Figure 5. Map of Section 1 of the project area, showing locations of Shovel Tests 1-7. 


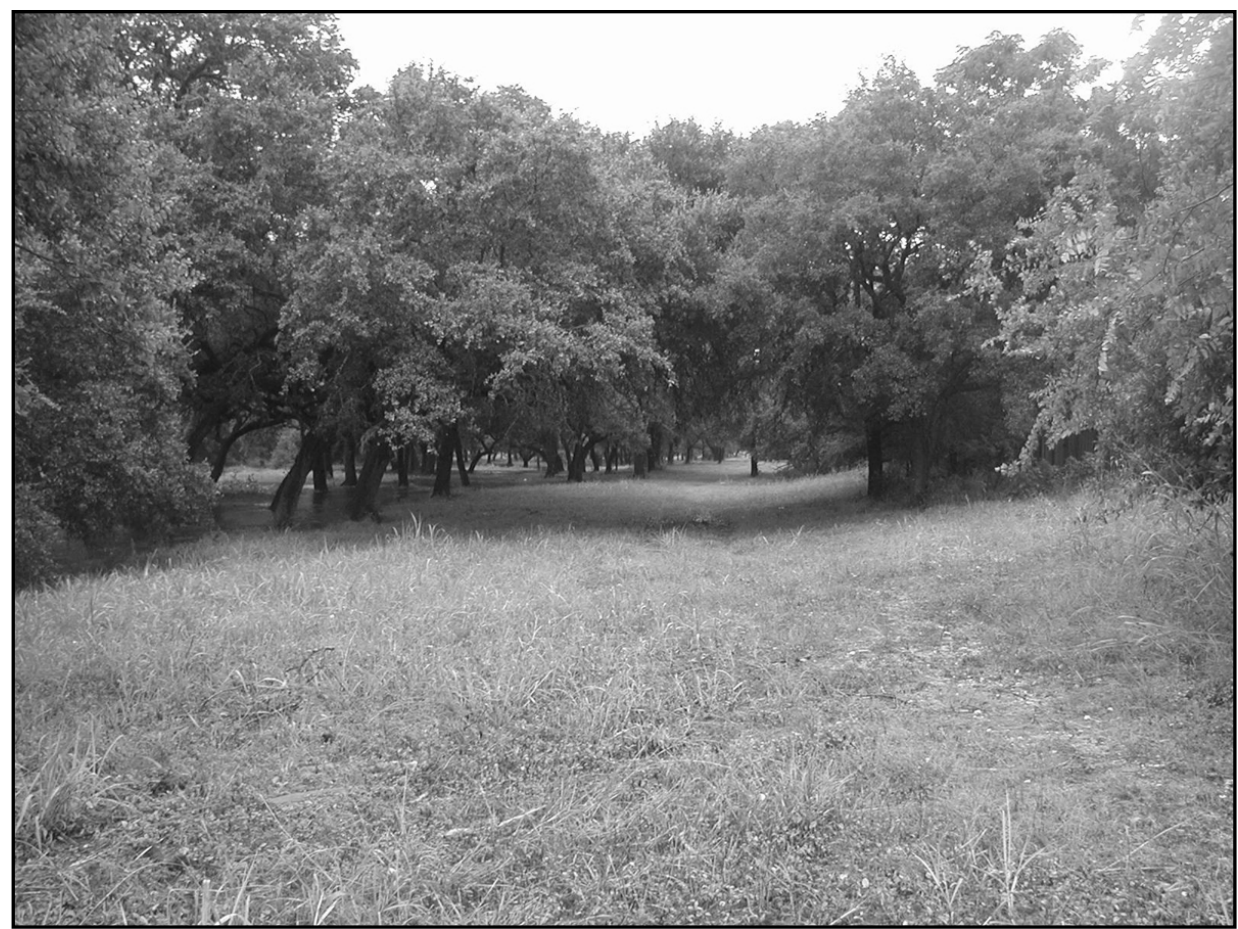

Figure 6. Photograph of greenbelt in Section 1 of the project area.

Section 2 of the project area, from Henderson Pass downstream to within $750 \mathrm{ft}$. (228.6 m) of Jones Maltsberger Road (see Figures 2 and 7), contained the widest portion of the greenbelt ROW and the deepest sediments. An abandoned and now overgrown asphalt road and parking lot is present on the northern bank of Lorence Creek near Henderson Pass. It measures approximately $730 \mathrm{ft} .(222.5 \mathrm{~m})$ in length and has a fence along its southeastern border (Figure 7). With the exception of a grassy area between this fence and the edge of the pavement, the entire parking lot vicinity is paved or highly disturbed and not viable for shovel testing. In the open grassy area north of the parking lot, the sediments are intermixed with machine rolled limestone and chert cobbles indicating disturbance. Despite this, one shovel test (ST 8) was placed along the trail route in this area. ST 8 recovered two pieces of unmodified debitage from Level 1 (Table 2) The dense gravel layer halted excavation at 11 cmbs. Given the extensive disturbance in this vicinity, it is likely that these specimens are in a secondary context.

In the widest portion of the survey area, southeast of the parking lot and fence, shovel tests were placed in two transects on either side of the trail route. STs 9,10 , and 11 were spaced $50 \mathrm{~m}$ apart, approximately 10 to $20 \mathrm{~m}$ from the creek along the northern bank (Figure 7). STs 12, 13, and 14 , placed in a transect $30 \mathrm{~m}$ north of the ST 9-11 transect, were also spaced $50 \mathrm{~m}$ apart. Starting with ST 15, placed on the trail route between STs 11 and 14, all shovel tests were spaced roughly $100 \mathrm{~m}$ apart and followed the trail route as indicated by the flagging tape markers.

ST 9 was placed southeast of the abandoned parking lot. Between this shovel test and the fence at the edge of the paved area, is an old 5-m-wide road cut that leads to a concrete ford of Lorence Creek (Figure 7). The sediments within this abandoned road appear to be severely eroded and redeposited. ST 9 recovered three pieces of lithic debitage (Table 2). All three are large flakes, ranging in length from $51.87 \mathrm{~mm}$ to $87.65 \mathrm{~mm}$. Due to this positive shovel test, three additional shovel tests were placed $5 \mathrm{~m}$ away from ST 9 in three directions (Figure 7). STs 9A, 9B, and $9 \mathrm{C}$ were all negative (Table 2). ST 9B was the deepest shovel test dug during the survey encountering the gravel layer at $68 \mathrm{cmbs}$. ST 9A only went down $5 \mathrm{~cm}$ before encountering gravels associated with the old road cut. 


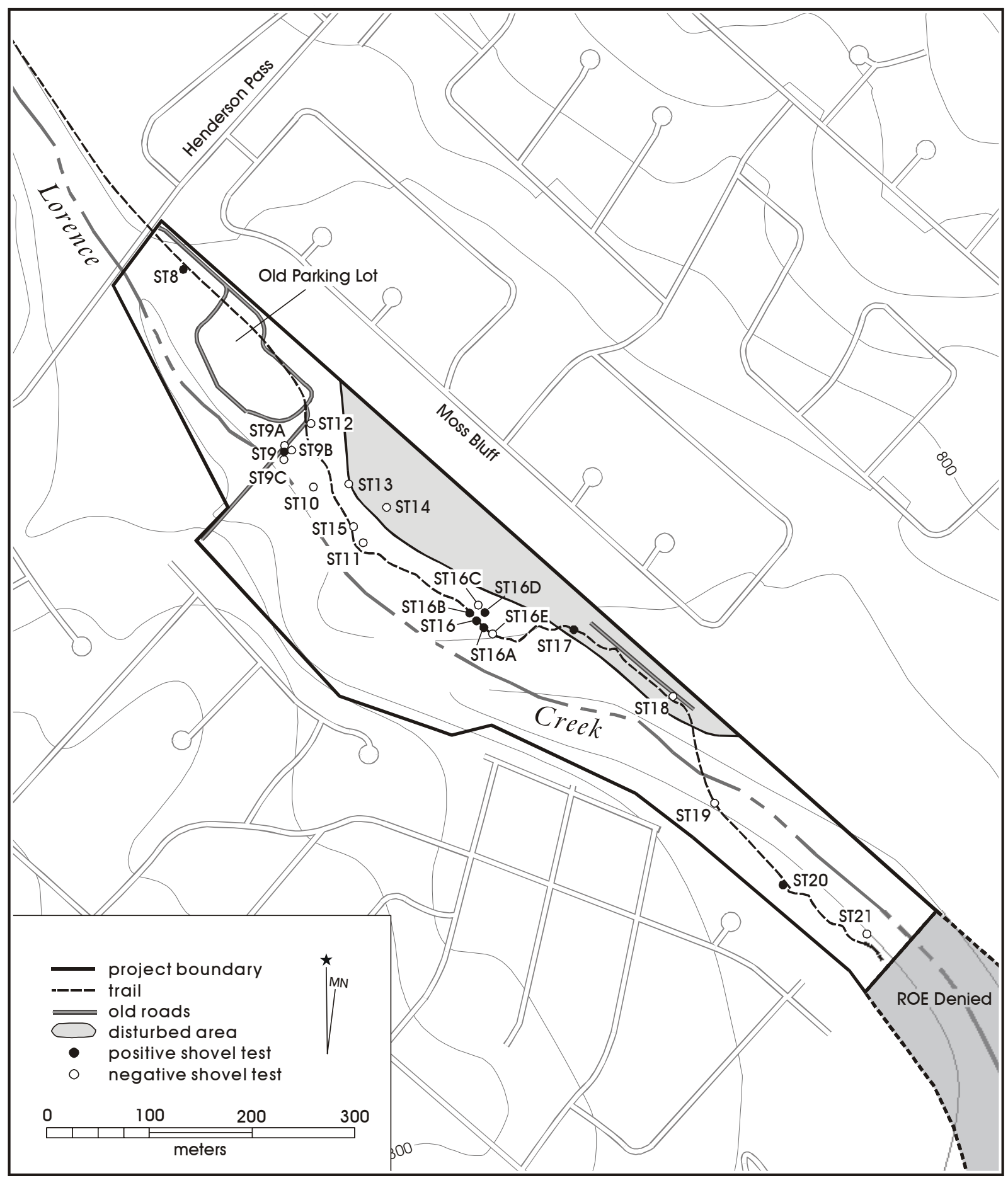

Figure 7. Map of Section 2 of the project area, showing locations of Shovel Tests 8-21. 
The southern bank of the creek in the widest portion of the project area consists of the broad creek bed and a low bank of sediments disturbed by grading for housing developments. Since the planned trail does not impact this highly disturbed area, no shovel tests were placed in the low-lying, disturbed southern bank adjacent to Chittam Woods and Oak Castle streets (Figure 2 and Figure 7).

ST 16 encountered unmodified lithic debitage in a buried, in situ context and prompted additional shovel tests and the designation of the area as Field Site 1. The site was later designated 41BX1581. The results of the shovel tests are detailed in the nest section of this report.

The shovel tests (STs 17-21) excavated within the remainder of the project area were in disturbed contexts. ST 17, roughly $100 \mathrm{~m}$ east and downstream of ST 16, recovered two pieces of unmodified debitage (Table 2). ST 17 is in an old road cut that turns to the drainage ditch separating the project area from Moss Bluff Road (Figure 7). The shovel test revealed mottled, heavily disturbed deposits. ST 18, which was culturally sterile, is also in the disturbed context of the road cut and is $40 \mathrm{~m}$ from a man-made drainage ditch that cuts across the creek bank and down into the creek. The trail follows this cut and crosses to the southern bank of the creek. STs 19, 20, and 21, on the southern bank of the creek (Figure 7), were excavated in deeper sediments; however this area has been heavily disturbed by grading done for housing development. ST 19 was shallow (only $19 \mathrm{~cm}$ deep) and culturally sterile (Table 2). ST 20 recovered one piece of debitage from Level $1(0-10 \mathrm{cmbs})$. A plastic fragment from Level 1 of ST 21 was not collected. A few meters downstream of ST 21, a large drainage ditch was marked with no less than five no trespassing signs. These signs identify the end of the project ROW. The archaeological survey and the flagging tape marking the proposed trail route ended here (see Figure 7).

\section{Site $41 B X 1581$}

ST 16 recovered three pieces of debitage from within moderately deep sediments $(45 \mathrm{~cm})$ with no signs of disturbance. To discern whether these materials represented isolated finds or a site, five more shovel tests were placed in the area (Figure 7 and Figure 8).

ST $16 \mathrm{~A}$ was placed $5 \mathrm{~m}$ southeast of ST 16 along the proposed trail and recovered two pieces of debitage (Table 2). ST 16B, $5 \mathrm{~m}$ northwest of ST 16 and also on the proposed trail, recovered one piece of debitage from Level 1 and one from Level 2 (Table 2). ST 16C, 5 m north of ST 16, was culturally sterile. ST 16D, 5 m east of ST 16 and farthest up the bank from the creek, had the highest density of artifacts including one thin biface fragment (Figure 9) recovered from Level 2 (10-20 cmbs; Table 2). ST 16E, located $5 \mathrm{~m}$ southeast of ST 16A and on the proposed trail, was culturally sterile.

The nine pieces of unmodified debitage from the site are a mix of large, early reduction flakes, small, thin tertiary flake fragments, and battered angular debris. The single biface recovered from this site is a proximal fragment that is 39 $\mathrm{mm}$ long, $43 \mathrm{~mm}$ wide, and $8 \mathrm{~mm}$ thick (Figure 9). It is well-thinned, well-trimmed, and symmetrical with parallel sides. It was broken during manufacture. The artifact is not temporally diagnostic.

On the basis of the number of cultural materials recovered from shovel tests in this area, this location was designated Field Site 1 (41BX1581). The site is bounded by Lorence Creek on the southwest, by negative ST $16 \mathrm{C}$ on the north and negative ST 16E on the southeast. The area northeast of the site has been extensively disturbed by bulldozing associated with a housing development. Figure 8 shows the estimated site boundaries and the edge of the area north of the site that has been extensively disturbed. Although the site, as currently recorded, is only about $20 \mathrm{~m}$ in diameter, it may have once extended into the bulldozed area to the northeast.

The artifacts recovered from STs 16, 16A, and 16B show a low artifact density (only two artifacts per shovel test) along the edge of the creek bank in the proposed footprint of the trail. ST 16D, farther up the gentle slope of the low terrace, has a higher density of cultural materials, suggesting the densest part of the site may be away from the creek's edge. If this is the case, the best place for the trail to pass through the site is across the lower density deposits along the edge of Lorence Creek, as is currently planned.

\section{Summary and Recommendations}

\section{Summary}

The hike-and-bike trail along the Lorence Creek Greenbelt is, for the most part, a wide, gravelly creek bed. Sediments, when present, are shallow and on very low terraces, heavily impacted by earth moving associated with housing 


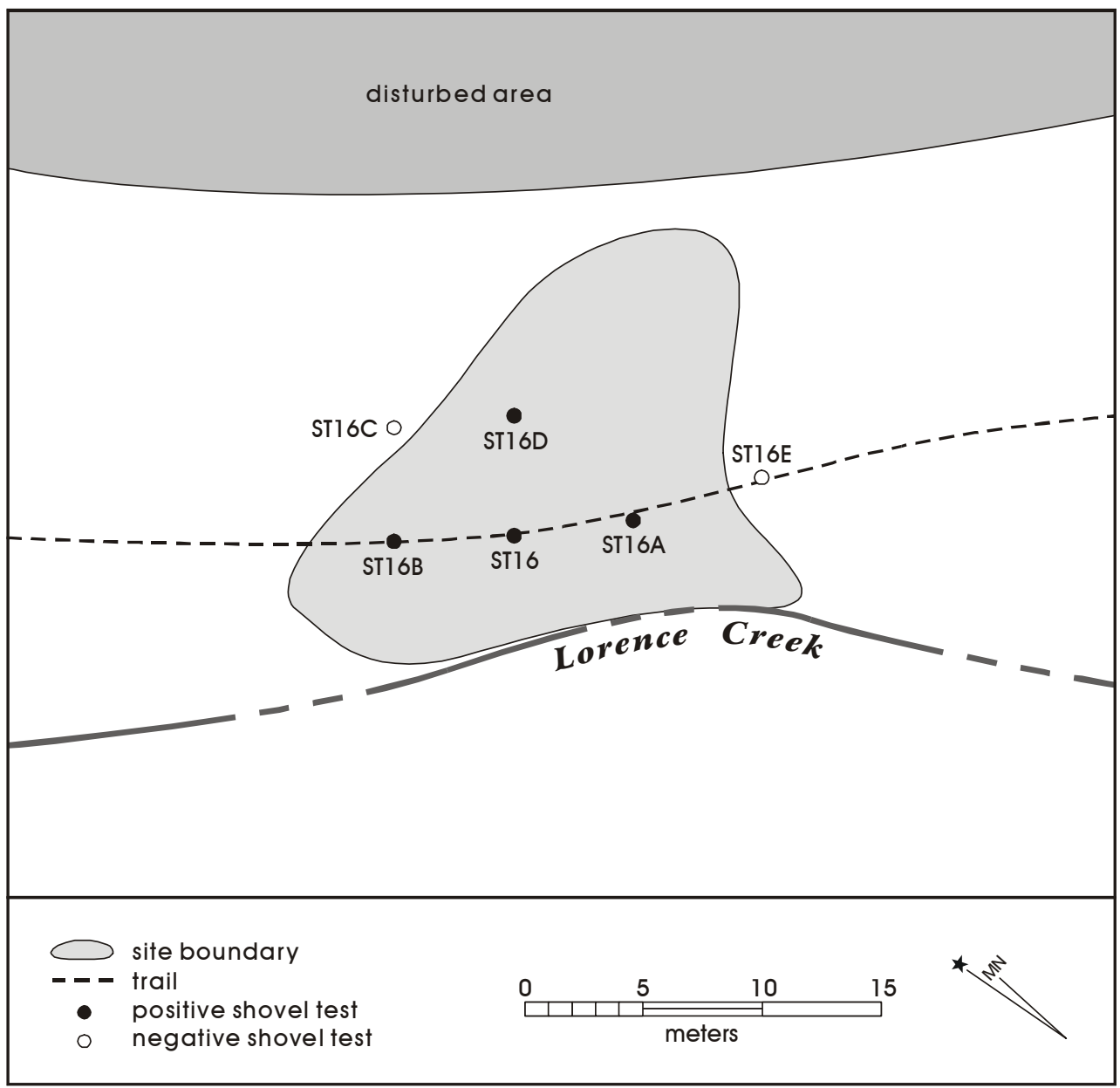

Figure 8. Map of $41 B X 1581$ showing locations of shovel tests, approximate site boundary, and disturbed area northeast of the site.

developments and by recurrent low- and high-velocity flooding. The areas north of the creek adjacent to Moss Bluff Street and south of the creek adjacent to Oakline Road (see Figure 2) have higher terraces and deeper sediments but are, with few exceptions, also extensively disturbed by old road cuts and recent housing developments. The entire project area has been subjected to archaeological survey, utilizing surface reconnaissance and 29 shovel tests. Of the 10 shovel tests that yielded artifacts, only those within site 41BX1581 had no obvious indications of disturbance.

The six positive shovel tests not associated with 41BX1581 are all in areas disturbed by a number of agencies. ST 1 was in recently deposited sediments with cultural material in secondary context. The area near ST 8 has been impacted by landscaping and parking lot construction. STs 9 and 17 were in areas disturbed by old, abandoned road cuts. STs 13 and 20 were on terraces in areas that had been disrupted by landscaping for housing developments.

41BX1581 is located in one of the few areas in the greenbelt that shows no direct evidence of disturbance. Of the six shovel tests excavated to define the site, four were positive for artifacts. Nine pieces of unmodified debitage and one nondiagnostic biface fragment were recovered from the site (Table 2 and Figure 9). No features were defined on-site and it appears that the cultural materials may represent the southern edge of a site that extends out of the project ROW. 


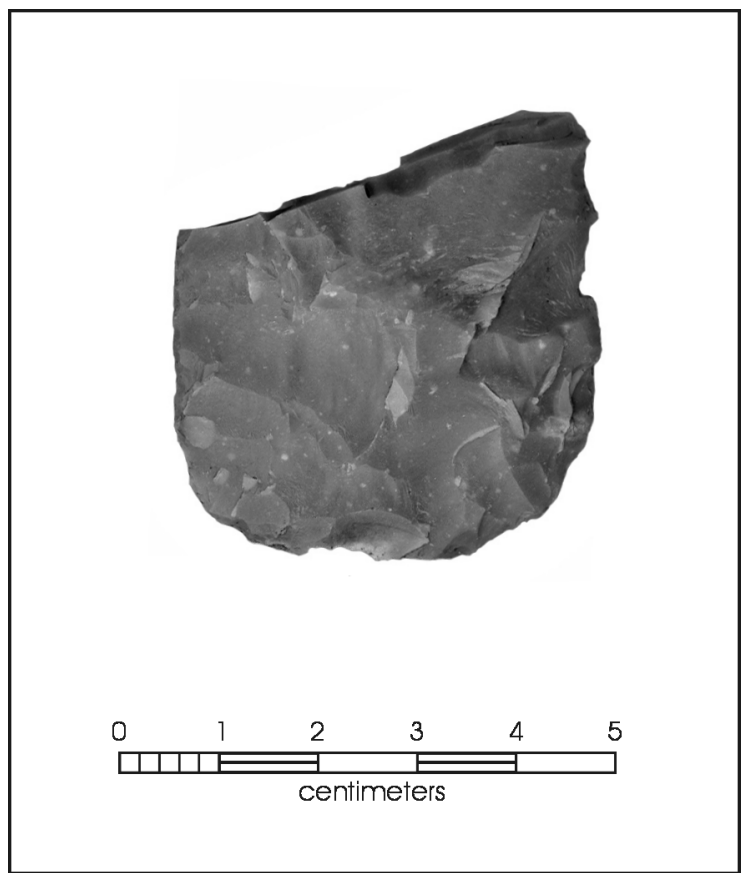

Figure 9. Biface fragment recovered from Shovel Test 16D, Level $2(10-20 \mathrm{cmbs})$.

\section{Recommendations}

Deposits in much of the project area have been severely impacted by low- and high-velocity flooding and neighborhood developments. The few isolated cultural materials found outside of 41BX1581 are in a secondary depositional context. Based on the sparse cultural materials from 41BX1581 and the lack of features, it is recommended that the site is not eligible for nomination to the National Register of Historic Places and does not warrant designation as a State Archeological Landmark. The Center for Archaeological Research recommends that construction of the proposed hike-and-bike trail in the Lorence Creek Greenbelt proceed as planned. 


\section{References Cited}

Bomar, G. W.

1995 Texas Weather. University of Texas Press, Austin.

Fox, A. A.

1973 An Archeological Survey of the Northeast Preserve and J Street Park San Antonio. Texas Archeological Research Laboratory, University of Texas at Austin.

1977 An Archaeological Assessment of the San Antonio 201 Wastewater Project. Archaeological Survey Report, No. 41. Center for Archaeological Research, The University of Texas at San Antonio.

Hester, T. R., F. A. Bass, A. A. Fox, T. C. Kelly, M. F. Chadderdon, and E. S. Harris

1974 Archaeological Survey of Areas Proposed for Modification in the Salado Creek Watershed, Bexar County, Texas. Archaeological Survey Report, No. 3. Center for Archaeological Research, The University of Texas San Antonio.

Katz, P. R.

1987 Archaeological Mitigation at 41BX300, Salado Creek Watershed, South-Central Texas. Archaeological Survey Report, No. 130. Center for Archaeological Research, The University of Texas San Antonio.

McGraw, A. J., and F. Valdez

1978 Investigation of Prehistoric Rockshelter and Terrace Sites along Portions of the Salado Creek Drainage, Northern Bexar County, Texas. Archaeological Survey Report, No. 55. Center for Archaeological Research, The University of Texas San Antonio.

Norwine, J.

1995 The Regional Climate of South Texas: Patterns and Trends. In The Changing Climate of Texas: Predictability and Implications for the Future, edited by J. Norwine, J. R. Giardino, G. R. North and J. B. Valdez, pp. 138-154. Cartographics, Texas A\&M University. College Station, Texas.

Tomka, S. A., and Robinson, R. C.

2000 The McAllister Park Roadway System Extension Project, San Antonio, Texas. Archaeological Survey Report, No. 301. Center for Archaeological Research, The University of Texas at San Antonio.

Taylor, F. B., R. B. Hailey, and D. L. Richmond

1991 Soil Survey of Bexar County, Texas. United States Department of Agriculture, Soil Conservation Service, Washington, D.C. 
